\title{
Music and the Aura of Revolution MARK LEVINE
}

Department of History, University of California, Irvine, Irvine, Calif., and Distinguished Visiting Professor, Center for Middle Eastern Studies, Lund University, Lund, Sweden; e-mail: mlevine@uci.edu doi:10.1017/S002074381200092X

It has become something of a commonplace to argue that music played an important role in the revolutionary upheavals that overthrew the Bin 'Ali regime in Tunisia and forced Husni Mubarak from power in Egypt. This recognition let the larger scholarly community-indeed, the world - in on a secret that a small group of MENA scholars have for decades been trying to share: it's not merely that music is society, as Jonathan Shannon argues in his contribution to this roundtable; it's society in "Real 3D," at once a microcosm, mirror, and prism of "all the social forces and contradictions of culture, politics, and history." As a mirror, music reflects society's contending forces back onto itself. Under the right conditions it also refracts them prismatically, acting as a filter and an amplifier that brings (and sometimes forces) subaltern sentiments into the public consciousness. Music, like other art forms, can help foster and sustain social and political change.

Tunisian rapper El Général (born Hamada bin 'Amr) and Egyptian singer Ramy Essam are two of the most well-known examples of how music has challenged the social, cultural, and political norms and boundaries that supposedly define Arab/Muslim societies. Both have reflected and amplified the revolutionary sentiments of young people across the Arab world, becoming global symbols of the aesthetic power of the Arab uprisings. El Général's song "Rais Lebled" (President of the Country), in which he promises to "talk without fear" to President Bin 'Ali, became the anthem of a youthled protest movement that morphed into a revolution in a matter of weeks. His arrest on Christmas Eve 2010 was seen as a direct attack on Tunisian youth, bringing even more people onto the streets (often chanting the words to his song) and helping solidify the momentum of the still inchoate revolution. In Egypt, Ramy Essam took a different path to become an iconic voice of the revolution. A metalhead turned aspiring folk/pop singer, Essam left his home town of Mansoura for Midan Tahrir on 1 February 2011, armed with a guitar and change of clothes. Within twenty-four hours he had written "Irhal!" (Leave!), which quickly became the unofficial anthem of Tahrir. From then until Mubarak's departure Essam performed "Irhal!" innumerable times per day, before crowds ranging from thousands in the afternoon sun to the far smaller contingent of late-night Tahrir denizens, for whom his performances joined the four a.m. conga lines as staples of the Midan's famed graveyard shift.

The post "revolution" trajectories of El Général and Ramy Essam diverged significantly. El Général has not played a major role in the post-Bin 'Ali public sphere. Essam, however, has been a fixture at every subsequent occupation of Tahrir. This, coupled with his well-publicized detention and torture by security forces in March 2011, increased his prestige among Ultras, working class and "street youths" who aren't adequately represented by the main revolutionary movements. "My role," as Essam told me, "is to take what people are feeling most deeply and put it into words that can speak to 
everyone over and over again." As a leading public intellectual of the foot soldiers of Tahrir, he does this not only through his music but also through an unending stream of meetings, interviews, and impromptu discussions with fans who approach him seeking encouragement, advice, and solace.

The Arab Spring did not produce its own heavy metal anthem, but metal is an important strand of the DNA of the Arab uprisings. Essam's music, for one, is very much an unplugged version of the metal he longs to play. My interviews with dozens of leading Egyptian, Tunisian, and Moroccan activists reveal that a large share of the revolutionary cadres in their countries came of age as serious fans of extreme heavy metal. The foreign origins and do it yourself ethos of the metal scenes, the marginalization from the mainstream of Arab societies, the need to sustain small-group solidarity, the focus on noncommodified, internet-based networks for disseminating their art, and the inherently subversive messages of the genre (where themes of corruption, meaningless violence, and decay naturally called to mind the political realities of their societies) -all of these enabled metal scenes across the Arab world to function as incubators of political activism.

Rap and metal are by no means the only genres of music that have inspired and mobilized people during the last two years of conflict. Traditional "folk" artists and groups have played a powerful role in the protests. Syrian singer Ibrahim Qashush, who transformed lyrics from the traditional ' $a r a \bar{d} d a$ style into revolutionary chants, was brutally murdered for his activism. In Egypt, the well-known folklore group Tanboura, which has led a national revival of the simsimiyya music of the Nile Delta, thankfully fared much better. The group gave one of the most celebrated Tahrir performances and continues to support the revolution. They were joined in Tahrir by a who's who of the new generation of Egyptian folklore-influenced bands, including Mustafa Sa id and Wust El Balad.

Each genre of music motivated a different group in the protests, but it was El Général, Essam, and other young artists who most directly gave voice to the despair and anger of a generation. Their songs were a core component of the broader "sonisphere" that reoriented the public spheres of their countries from fear and obedience toward revolt. Yet even the most powerful and popular music functions more as a dependent than an independent variable in the larger dynamics of political struggle. For every El Général or Ramy Essam, many other rappers and musicians (such as El Haked in Morocco and Palestinian Rapperz in Gaza) have faced harassment and even imprisonment for their music and activism without fueling broader protests. It is clear the success of a revolution does not depend on a song. But exploring revolutions through their musical soniscapes illuminates social and political aspects of change that might otherwise go underappreciated, if not unnoticed.

As one example, such studies can trace specific ways in which the spread of the internet has created new forms of indigeneity and hybridity that have proven crucial for the development of revolutionary activism in the region. The internet has radically changed the role of migration and diasporization in the evolution of pop music genres. As Carl Davila points out in this roundtable, the evolution of Rai was profoundly shaped by the migration of Algerians to and from France. Today, however, the world can come to an artist through a computer. Thus have emerged Tunisian or Gazan "beatmakers" with an encyclopedic knowledge of American blues and soul and Moroccan and Egyptian metal 
artists who can parse the most minute difference between subgenres of Scandinavian extreme metal without ever having left their home country.

Not only do artists have unprecedented access online to a huge chunk of the entire corpus of global musical production, but also almost any artist with the time, talent, and drive can produce and circulate professional quality music thanks to the revolution in inexpensive recording technologies. I argue that these two developments have transformed the meaning of indigeneity and hybridity in the Arab world (and no doubt beyond). Local artists are not merely creating hybrids of "Western" styles like hip hop, rock, and metal and local types of music. Rather, these genres have been fully indigenized-it makes no more sense to call hip hop a genre "foreign" to Tunisia than it does to call classical music foreign to the United States. What's more, the genres have been fundamentally transformed through constant experimentation and mixings of disparate sources into new forms of music expression. Two generations ago Western musicians would come to Morocco or Egypt in search of authenticity and inspiration in "traditional" music. Today they come in search of the future.

This process of indigenization has a direct counterpart in the political sphere. The role of Western thinkers, strategies, and organizations is one of the more vexing questions surrounding the emergence of revolutionary movements in the Arab world today. But as the example of music shows, the very terms of the question are wrong. Most Arab activists don't look at the writings of Gene Sharp or the civil-society strategies of American or European organizations as "foreign" imports (despite the best efforts of their governments to portray them as such). Rather, they join them with Leninist organizing tactics, the hacker's credo, Latin American horizontalism, Muslim rituals of public worship, Serbian civil-resistance strategies, and whatever other tactics might be usefully deployed against their regimes. The global circulation of knowledge, practices, and cultural expression is at the core of what could be termed the "new indigeneity" in the Arab world. Miriam Cooke captured this dynamic when she described the "improvisational" core of dissidence in the Syria of Hafiz al-Asad. ${ }^{4}$ Whether in music or politics, the most successful "improvisers" are those who have a wide repertoire of elements to draw from, while also having a strong sense of the overall approach they need to take to fit the broader "song." And even then, as the unfolding bloodbath in Syria reminds us, the most well prepared "solos" can veer dangerously out of tune if the larger group is not well rehearsed and prepared for sudden changes in the key (e.g., a massive ramping up of repression against nonviolent demonstrations).

Another area warranting more research concerns how the digital/internet revolution has enabled a reaestheticization of political struggle that is remarkably well suited to youth-led protests. One of the most important debates in the history of cultural theory, between Theodor Adorno and Walter Benjamin, surrounded the question of how the mechanical reproduction of art and its commodification would impact art's "aura" and thus its ability to act as an agent or amplifier of social change. Both thinkers believed the singularity and incommensurable value that previously "surrounded" individual works of art, constituting their "aura," was lost with the mass (re)production and commodified distribution of art. Benjamin considered this a positive development that would liberate art from its traditional role supporting power structures, enabling it to carry new and even revolutionary visions of the future to the masses. Adorno was far less sanguine, believing that a commodified and highly ideological "aura of style" would replace the 
traditional aura of art as a "stereotyped appropriation of everything ... for the purpose of mechanical reproduction" that eliminated "every unprepared and unresolved discord."

The manner in which bebop, rock, punk, and hip hop were all co-opted, commodified, and defanged of their original political impetus bears out Adorno's fears about the power of the culture industry. But something has changed, radically, with the emergence of digital production, reproduction, and dissemination of music in the last decade. Put simply, the aura has returned to music. Today most rap, rock, metal, and traditional music of the kinds that were featured in the Arab uprisings are either disseminated for free on the internet or sold directly by the artists to fans. This decommodification of musical production and circulation has both freed the artists from dependency on government permission or corporate sponsorship and returned live performance to the center of musical experience. In so doing it has rejoined the frustrated desires of Adorno and Benjamin to locate and foster an art that could at once be widely disseminated and highly critical of structures of power (which Adorno describes as the "torn halves of an integral freedom, to which however they do not add up"3). It does this by encouraging the kinds of gatherings that are beyond the reach of the government and allied forces of social control. And with the synergy between social media networks and online musical distribution networks, the new aura can not only survive but also thrive in virtual space, emerging into the physical world stronger than ever.

The return of the "aura" to music and other forms of critical cultural production (art, poetry, graffiti, theatre, etc.) has renewed their authenticity, making them powerful weapons in the long-term war-of position, maneuver, and sometimes both-between subaltern forces and state power for hegemony. Music is helping to transform what Gramsci termed the "common sense" of the majority of people regarding their subordination to political and economic elites into a more politically sophisticated "good sense" that can be channeled by activists into mass political movements. Music may not create revolution with a song, but studying the way music functions in periods of societal unrest can provide us with important clues about the genealogy, dynamics, and potential trajectories of movements for social and political change. In the wake of the first great revolutionary wave of the 21 st century, and especially when coupled with its complex yet aesthetically and historically productive relationship with religious belief and practice in Islam, music emerges as one of the most fruitful areas of social life in the Middle East and North Africa to study, research, and teach. ${ }^{4}$

\section{NOTES}

\footnotetext{
${ }^{1}$ Max Harkheimer and Theodor W. Adorno, Dialectic of Enlightenment, trans. John Cumming (New York: Continuum, 1997), 127.

${ }^{2}$ Adorno, letter to Walter Benjamin, 18 March 1936, in Ernst Bloch, Aesthetics and Politics (London: Verso Books, 1980), 123.

${ }^{3}$ For a more in-depth discussion see Mark LeVine, "New Hybridities in Arab Musical Intifadas," Jadaliyya, October 2011. For a detailed history of the hip hop, metal, and rock scenes in the region, see idem, Heavy Metal Islam: Rock, Resistance and the Struggle for the Soul of Islam (New York: Random House, 2008).

${ }^{4}$ Miriam Cooke, Dissident Syria: Making Oppositional Arts Official (Durham, N.C.: Duke University Press, 2007), 85 .
} 